\title{
An experiment for rendering apparent the adjusting power of the eye
}

\section{Reuben Phillips}

To cite this article: Reuben Phillips (1844) An experiment for rendering apparent the adjusting power of the eye, Philosophical Magazine Series 3, 24:161, 474-475, DOI:

$10.1080 / 14786444408644899$

To link to this article: http://dx.doi.org/10.1080/14786444408644899

册 Published online: 30 Apr 2009.

Submit your article to this journal $[\pi$

Џ Article views: 2

Q View related articles $\asymp$ 
comparative value of the African guano as a manure. This depends, first, on the amount of phosphates, and secondly, on that of the ammonia, or substances capable of affording that ingredient. But it is also evident that the state in which the nitrogenous compounds are contained in the manure must be of some importance, $i$. $e$. whether they exist in the form of ammonia, as is the case with the guano submitted by us to analysis, or in the state of uric acid*.

It is probable that this African guano would prove extremely stimulating to vegetation at first, but that its power would soon be spent, unless previous to its employment it were mixed with some substance capable of fixing the ammonia, such as gypsum or charcoal, as recommended by Boussingault and Payen; while that containing uric acid would, from the slow decomposition of this substance, prove for a long time a constant source of nitrogen proportionate to the growth of the plants.-Chem. Gazette, May 1, 1844.

\section{PROCESS FOR OBTAINING IRIDIUM. BY M. E. FREMY.}

In order to obtain iridium, M. Fremy treats the chloride of iridium with hydrochlorate of ammonia; a precipitate of a brownishred colour is formed, which is a compound of the bichlorides of iridium and osmium with hydrochlorate of ammonia ; in order to separate these a current of sulphurous acid is passed into the two salts suspended in water, by this the iridium is dissolved, and the osmium remains precipitated in the state of a red salt. 'The soluble salt of iridium thus obtained crystallizes in large brown prisms from solution in hydrochlorate of ammonia; when it is calcined in a current of hydrogen, it yields pure iridium, which retains the crystalline form of the salt.

The soluble salt of iridium, under the influence of chlorine, reproduces the black insoluble salt, and serves for the preparation of all the compounds of iridium.-Journ. de Ph. et de Ch., Mars 1844.

\section{AN EXPERIMENT FOR RENDERING APPARENT THE ADJUSTING POWER OF THE EYE. BY REUBEN PHILLIPS.}

If the head be turned away from a window, and if a small bright piece of metal, as a knitting-needle, be held within a few inches of the eye, so that the needle may be distinctly seen, taking care so to place the head as to intercept as little as possible of the light which can fall on the needle;-things being thus arranged, if the eye be directed to a wall, a few feet distant, for a few seconds, and then,

* "The value of a manure depends therefore on the proportion of nitrogenized organic matter, and especially in relation to the non-nitrogenous organic substances, and lastly, on the decomposition of the quaternary substances being gradually effected, and so keeping pace with the progress of vegetation." And again, "A manure entirely decomposable into its soluble and gaseous products in the course of a single year will be capable of producing as great an effect on the first crop as five times the quantity of another manure which would require five years for its ultimate decomposition, but then the latter will furnish useful products during a period five times longer."-Payen and Boussingault in Ann. de Chim. et de Phys., t. iii. pp. 67 and 70 . 
if the attention be momentarily directed to the appearance of the needle, its outline is seen to be indistinct, and those parts which re, flect most light are seen with luminous protuberances, exhibiting all the appearances of light imperfectly focalized on the retina. If the eye be kept directed to the needle for but a very short time (accompanied perhaps by an effort to see distinctly), the ill-defined image rapidly contracts to perfect vision.

Topsham, near Exeter, March 4, 1844.

\section{DOUBLE CARBONATE OF AMMONIA AND MAGNESIA. \\ BY M. P. A FAVRE.}

This salt may be obtained in several modes; by agitating carbonate of magnesia in a solution of carbonate of ammonia and filtration, the solution rapidly deposits crystals on the sides of the vessel containing it, and these are right rectangular prisms; when they are collected and spread on filtering paper, they dry rapidly; after being inclosed in a bottle, when perfectly dry, they did not yield any ammoniacal odour, on opening the bottle several days afterwards.

The portion remaining on the filter, again submitted to similar treatment, yielded a solution which afforded more crystals, and eventually it altogether assumed a granular aspect, and became entirely the salt in question, of which large quantities may be thus obtained. The analyses which were made of this salt were performed upon crystals which were deposited from the filtered liquor, and not those which granulated.

Another method for obtaining large quantities of these crystals, and in a very pure state, consists in mixing a saturated solution of bicarbonate of magnesia with one of carbonate of ammonia; the double carbonate of magnesia, being very slightly soluble, notwithstanding a great excess of carbonate of ammonia, but few crystals are obtained by the first method above described; whereas the bicarbonate of magnesia being more soluble, brilliant and well-defined crystals of the double carbonate are obtained in a few seconds after it is mixed with the solution of carbonate of ammonia.

This salt in fine prismatic crystals yielded by analysis as under :-

$$
\begin{aligned}
& \begin{array}{llll}
\text { Magnesia . . . . } & 15 \cdot 77 & \mathbf{1 5} \cdot 92 & 15.8
\end{array} \\
& \text { Carbonic acid .. } 34.90 \quad 35.00 \quad \text {... } \\
& \begin{array}{rrrr}
\text { Hydrogen . . . . . } 6.70 & 6.70 & \ldots & \ldots
\end{array} \\
& \begin{array}{llll}
\text { Azote........... } & 11.60 & \ldots & \ldots \\
\text { Oxygen } . . . \cdots & \frac{31.03}{100^{\circ}} & \ldots & \ldots
\end{array}
\end{aligned}
$$

These analyses indicate the annexed formula:

$$
\text { ( } \mathrm{CO}^{2}, \mathrm{MgO}, \mathrm{CO}^{2} \mathrm{H}^{4} \mathrm{AzO}, 4 \mathrm{HQ} \text { ), }
$$

which gives the following numbers:-

$$
\begin{aligned}
& \text { Magnesia ....... } 16 \cdot 28 \\
& \text { Carbonic acid .... } 34 \cdot 70 \\
& \text { Hydrogen ....... 6. 6.31 } \\
& \text { Azote ........ 11.17 } \\
& \text { Oxygen .......... } \frac{31 \cdot 54}{100^{\circ}}
\end{aligned}
$$

